\title{
KONJUNGSI SEBAGAI PERTALIAN MAKNA ANTARKALIMAT DALAM RUBRIK FUN SCIENCE REPUBLIKA
}

\author{
Sauzan Az Zahra \\ SMP Negeri 92 Jakarta \\ E-mail: sauzanaz.saz@gmail.com
}

\begin{abstract}
ABSTRAK
Tujuan penelitian ini yaitu mendeskripsikan penggunaan konjungsi sebagai pertalian makna antarkalimat pada rubrik Fun Science Republika edisi Januari-April 2017. Metode penelitian yang digunakan, yakni deskriptif-kualitatif. Hasil penelitian menunjukkan bahwa konjungsi sebagai pertalian makna antarkalimat pada rubrik Fun Science Republika edisi Januari-April 2017 dapat mempertahankan keutuhan wacananya, yakni kohesi dan koherensi, dimana informasi kalimat yang satu dengan lainnya bertalian dan mendukung adanya keserasian terhadap topik pada masing-masing ujaran. Penggunaan konjungsi sebagai pertalian makna antarkalimat diperoleh sejumlah 58 penanda dari 58 pasang ujaran. Penggunaan tersebut menandai pertalian makna pada sepuluh kategori, yakni pertalian makna penjumlahan diperoleh sebanyak $7 \%$ atau 4 penanda, perturutan $22 \%$ atau 13 penanda, perlawanan $21 \%$ atau 12 penanda, lebih $3 \%$ atau 2 penanda, sebab akibat $9 \%$ atau 5 penanda, waktu $17 \%$ atau 6 penanda, syarat $3 \%$ atau 2 penanda, cara 3\% atau 5 penanda, kegunaan 2\% atau 1 penanda, dan penjelasan $7 \%$ atau 4 penanda. Konjungsi 'perturutan' lebih banyak digunakan sebagai penanda hubungan informasi antarkalimat dengan jumlah $22 \%$ karena informasi perturutan biasanya diwujudkan tidak dalam satu kalimat saja, namun memerlukan beberapa kalimat untuk menyatakan hubungan tersebut. Dengan demikian, diperlukan konjungsi antarkalimat untuk menghubungkan informasi-informasi tersebut sehingga mendukung topik utama. Hasil penelitian ini dijadikan sebagai panduan pengembangan perencanaan pelaksaan pembelajaran pada KD 3.6 dan 4.6 SMP kelas VII beserta pengembangan materi ajarnya dengan berdasarkan Kurikulum 2013 Tahun 2016.
\end{abstract}

Kata kunci: konjungsi, pertalian makna antarkalimat, rubrik Fun Science Republika

\begin{abstract}
The purpose of study is to describe the use of the conjunction as a relation between the meaning of the sentence in the rubric of Fun Science Republika on January-April 2017 edition. The research method used is descriptive-qualitative. The results showed that the conjunction as a relation between the meaning of the sentence in the rubric of Fun Science Republika on January-April 2017 edition can maintain the integrity of the discourse, namely the cohesion and coherence. Cohesive and coherence of these sections is determined by one of the markers of the relationship, i.e., conjunctions are used as markers of relationship and connection to the meaning of the information


revealed that one sentence with the other sentence. The information related to each other and support the existence of harmony to the topic on each speech. The use of the conjunction as a relation between the meaning of the sentence obtained a number of 58 markers of 58 pairs of speech. The use of the mark in relation to the meaning of the ten categories, i.e. the relation of meaning the sums obtained as much as $7 \%$ or 4 markers, perturutan $22 \%$ or 13 markers, resistance $21 \%$ or 12 marker $3 \%$ or more, 2 markers, as the result of a $9 \%$ or 5 bookmarks, time $17 \%$ or 6 markers, terms of $3 \%$ or 2 markers, $3 \%$ or 5 way marker, uses $2 \%$ or 1 bookmark, and explanation of the $7 \%$ or 4 markers. The conjunction 'sequence' is more widely used as a marker of relationship information between sentences with a total of $22 \%$ since the information sequence usually is manifested not only in one sentence, but it needs a few sentences to express the relationship. Thus, the necessary conjunction antarkalimat to link the information so that it supports the main topic. The results of this research as a guide to the development planning implementation study on KD 3.6 and 4.6 class VII junior high school along with the development of teaching materials based on 2013 Revision Curriculum at 2016.

Keywords: conjunction, connection between sentence meaning, Republika's Fun Science rubric

\section{PENDAHULUAN}

Wacana tersusun oleh kesatuan informasi antarkalimat. Informasi yang terdapat dalam kalimat yang satu dengan kalimat yang lain berkaitan erat sehingga informasi tersebut membentuk paragraf menjadi sangat padu. Kesatuan informasi yang padu inilah dijadikan sebagai keberhasilan wacana. Seperti yang dikatakan oleh Tarigan bahwa wacana sebagai satuan bahasa terlengkap dan tertinggi di atas kalimat dengan kohesi dan koherensi tinggi, berkesinambungan, mempunyai awal dan akhir nyata, serta disampaikan secara lisan maupun tulisan, misalnya melalui radio, televisi, koran, atau majalah (Tarigan, 1987). Dengan demikian, suatu wacana perlu mengandung kepaduan informasi baik dari segi kohesi maupun koherensinya untuk membentuk informasi yang utuh antarkalimat.

Surat kabar sebagai salah satu bentuk media massa cetak menggunakan ragam bahasa yang menuntut adanya kemudahan penyampaian informasi sehingga pembaca dapat memahami informasi yang ingin disampaikan dalam artikel-artikel surat kabar. 
Chaer (2010) menjelaskan bahwa ragam jurnalistik harus memelihara kesatuan dan kepaduan antarkalimat. Pemilihan surat kabar didasarkan pada penggunaan ragam bahasa yang jelas, mudah dimengerti, dan masih tetap mematuhi aturan bahasa.

Kata kata hubung bukan hanya sekadar merangkaikan antarkata, antarfrasa, antarklausa, antarkalimat, dan satuan yang lebih besar, tetapi juga merangkaikan ide atau gagasan karena tanpa ide yang jelas dalam antarbagian wacana akan menyulitkan menginterpretasi informasi yang ada dalam kalimat. Ditegaskan pula oleh Ramlan (1993) bahwa kata hubung tidak hanya berfungsi sebagai penanda hubungan di bidang bentuk, namun juga berfungsi sebagai penanda hubungan di bidang makna, dengan kata lain menandai pertalian informasi yang satu dan lainnya. Oleh sebab itu, kata penghubung dapat dijadikan sebagai indikator penanda keutuhan wacana, baik kohesi maupun koherensinya.

Kata hubung bahasa Indonesia memiliki bentuk penanda yang beragam dan makna yang berbeda, maka diperlukan suatu media yang memberikan gambaran penggunaannya (Utami, 2017). Kata hubung sebagai pertalian makna antarkalimat dapat menghasilkan sepuluh hubungan, antara lain penjumlahan, perturutan, perlawanan, lebih, sebab akibat, waktu, syarat, cara, kegunaan, dan penjelasan. Di samping itu, penggunaan bentuk kata hubung yang beragam disesuaikan dengan pertalian makna informasi antarkalimat. Berdasarkan pengamatan awal terhadap rubrik Fun Science Republika ditemukan bahwa penggunaan kata hubung sangat mendominasi sebagai penanda keutuhan wacana diantara bentuk kohesi yang lain (Kurniadi, 2017). Variasi konjungsi yang digunakan dalam wacana tersebut dapat membantu pelaksanaan pembelajaran unsur kebahasaan pada teks. 
Latar belakang tersebut dijadikan sebagai dasar pelaksanaan penelitian ini. Penelitian ini dilakukan untuk mendeskripsikan penggunaan konjungsi antarkalimat sebagai penanda hubungan dan juga pertalian informasi dalam membentuk keutuhan suatu wacana. Pemilihan Republika didasarkan atas hasil penelitian Lembaga Badan Pengembangan dan Pembinaan Bahasa sebagai surat kabar dengan penggunaan bahasa yang baik pada urutan kedua, sedangkan urutan pertama diduduki oleh Kompas. Alasan pemilihan rubrik Fun Science yaitu penyampaian informasi yang singkat dan padat menjadikan informasi yang disampaikan mudah dipahami melalui penggunaan ragam bahasa akrab, namun masih menaati kaidah yang berlaku. Dengan demikian, penggunaan konjungsi dalam menghubungkan informasi-informasi dengan penggunaan bahasa seperti itu, akan memudahkan penyampaian pokok pikiran penulisan suatu obyek.

Berdasarkan latar belakang tersebut, perumusan masalah dalam penelitian "Konjungsi Sebagai Pertalian Makna Antarkalimat dalam Rubrik Fun Science Republika Serta Implikasinya Terhadap Pembelajaran Bahasa Indonesia" yaitu bagaimana penggunaan konjungsi sebagai pertalian makna antarkalimat dalam rubrik Fun Science Republika.

Manfaat penelitian ini meliputi manfaat teoritis dan manfaat praktis. Manfaat teoritis, yakni penelitian ini diharapkan dapat menambah dan memperkaya pengetahuan mengenai teori wacana khususnya konjungsi. Pengetahuan teori tersebut berkenaan dengan penggunaan konjungsi sebagai penanda hubungan dan pertalian makna antarkalimat dalam membentuk keutuhan suatu wacana, kohesi dan koherensinya. Selanjutnya, manfaat praktis, yaitu penelitian ini diharapkan dapat menjadi bahan acuan penelitian satu tema yaitu mengenai "Konjungsi Sebagai Pertalian Makna 
Antarkalimat", konjungsi sebagai penanda hubungan dan pertalian makna antarkalimat. Penelitian ini juga dapat menjadi bahan acuan bagi pendidik pada tingkat SMP maupun SMA dalam materi ajar konjungsi pada teks.

\section{METODE}

Penelitian “Konjungsi Sebagai Pertalian Makna Antarkalimat dalam Rubrik Fun Science Republika Serta Implikasinya terhadap Pembelajaran Bahasa Indonesia" bertujuan untuk mendeskripsikan penggunaan konjungsi sebagai pertalian makna antarkalimat pada rubrik Fun Science Republika. Penggunaan konjungsi antarkalimat difokuskan pada sepuluh hubungan pertalian, yakni penjumlahan, perturutan, perlawanan, lebih, sebab akibat, waktu, syarat, cara, kegunaan, dan penjelasan. Selain itu, penggunaan konjungsi tersebut dideskripsikan kepaduannya dalam menghubungkan informasi kalimat yang satu dengan informasi kalimat lainnya suatu wacana, baik kohesi maupun koherensi. Sumber data penelitian yang digunakan yaitu kolom utama pada rubrik Fun Science Republika edisi Januari-April 2017 dengan total keseluruhan yaitu 14 kolom.

Prosedur penelitian ini meliputi langkah, pertama yaitu membaca sumber data penelitian, rubrik Fun Science Republika edisi Januari-April 2017 secara komprehensif dan cermat. Hal ini dilakukan untuk mencari penanda-penanda konjungsi antarkalimat pada masing-masing rubrik. Penseleksian tidak hanya berdasarkan unsur wacana yang dihubungkan oleh konjungsi tersebut, namun proses seleksi mencapai informasiinformasi antara kalimat yang satu dengan lainnya yang bertalian dengan konjungsi yang digunakan. Kedua, setelah penanda-penanda tersebut ditemukan, unsur wacana yang dihubungkan oleh konjungsi antarkalimat dicatat dalam kartu data sebagai pasang 
kalimat ujaran. Pada kartu data, pasang kalimat ujaran tersebut diklasifikasikan berdasarkan penanda konjungsi antarkalimat yang digunakan, unsur wacana yang dihubungkan, dan pertalian makna yang dihasilkan. Ketiga, memasukkan hasil penganalisisan awal dalam kartu data ke tabel instrumen penelitian. Keempat, menganalisis serta mendeskripsikan penggunaan konjungsi antarkalimat. Mula-mula penggunaan konjungsi antarkalimat dianalisis secara strukturnya untuk mendeskripsikan penanda yang digunakan dan unsur wacana yang dihubungkan. Kemudian, pasang kalimat ujaran dianalisis secara keseluruhan. Kalimat-kalimat yang mengandung satu topik dengan penggunaan konjungsi dalam pasang kalimat ujaran tersebut dianalisis kepaduannya, baik kohesi maupun koherensi. Instrumen penelitian yang digunakan untuk mendeskripsikan penggunaan konjungsi sebagai pertalian makna antarkalimat digambarkan pada tabel di bawah ini.

\section{Tabel 1. Instrumen Penelitian Konjungsi Sebagai Pertalian Makna Antarkalimat dalam Rubrik Fun Science Republika Edisi Januari-April 2017}

\begin{tabular}{|l|c|c|c|c|c|c|c|c|c|c|c|c|}
\hline \multirow{2}{*}{ No } & Pasang & \multicolumn{7}{|c|}{ Pertalian Makna Antarkalimat } & \multirow{2}{*}{ Analisis } \\
\cline { 3 - 11 } & Ujaran & 1 & 2 & 3 & 4 & 5 & 6 & 7 & 8 & 9 & 10 & \\
\hline & & & & & & & & & & & & \\
\hline & & & & & & & & & & & & \\
\hline & & & & & & & & & & & & \\
\hline
\end{tabular}

Tabel instrumen menggunakan pasang kalimat ujaran sebagai beberapa kalimat yang mengandung informasi yang sama sesuai dengan topik kalimat tempat konjungsi berada. Kemudian, penggunaan konjungsi antarkalimat sebagai penanda hubungan informasi-informasi dalam wacana difokuskan pada sepuluh pertalian makna, antara lain (1) penjumlahan, (2) perturutan, (3) perlawanan, (4) lebih, (5) sebab akibat, (6) 
waktu, (7) syarat, (8) cara, (9) kegunaan, dan (10) penjelasan. Penggunaan tabel instrumen di atas dijelaskan pada contoh berikut.

Persoalannya mereka khawatir setelah renovasi mereka tidak dapat berdagang di lokasi itu. (1) Di samping itu, mereka juga mengharapkan dapat menjadi pelaksana renovasi pasar tersebut. (2)

Pasang kalimat ujaran pertama menggunakan konjungsi di samping itu yang menghubungkan kalimat (1) "persoalannya mereka khawatir setelah renovasi mereka tidak dapat berdagang di lokasi itu" dengan kalimat (2) "mereka juga mengharapkan dapat menjadi pelaksana renovasi pasar tersebut". Selain konjungsi di samping itu digunakan sebagai penanda hubungan kalimat (1) dengan kalimat (2), juga menandai pertalian 'penjumlahan'. Informasi yang disampaikan pada kalimat (2) "para pedagang berharap dapat ikut serta merenovasi lokasi berdagang mereka" merupakan informasi tambahan dari kalimat (1) "bahwa para pedagang pasar merasa khawatir jika tidak dapat berdagang di lokasi mereka, lokasi setelah dilakukan renovasi”. Dengan demikian, pasang kalimat ujaran pertama merupakan pasang kalimat yang kohesif dan koherens karena kalimat (2) bertalian dengan topik ujaran yang dinyatakan pada kalimat (1) "kekhawatiran para pedagang" yang dihubungkan dengan penanda di samping itu sebagai pertalian 'penjumlahan'.

\section{HASIL DAN PEMBAHASAN}

Penelitian ini memperoleh data sebanyak 58 pasang kalimat ujaran yang menggunakan konjungsi antarkalimat sebagai penanda hubungan kepaduannya, baik kohesi maupun koherensi. Dari ke-58 pasang kalimat tersebut mengandung informasiinformasi yang saling bertalian satu sama lain. Dengan demikian, hubungan informasi tersebut tidak hanya diwujudkan dari dua pasang kalimat, namun juga mencapai delapan 
pasang kalimat yang memiliki kepaduan informasi. Selain itu, kepaduan informasi tidak hanya diwujudkan dari adanya keserasian hubungan kalimat yang satu dengan kalimat lainnya, tetapi data penelitian juga menemukan adanya pasang ujaran yang berupa paragraf. Maksudnya, kepaduan informasi diwujudkan dari paragraf yang satu dengan paragraf lainnya. Adanya kepaduan informasi baik antarkalimat maupun antarparagraf menjadikan wacana rubrik Fun Science Republika mencapai sifat kohesif dan koherensinya. Dapat disimpulkan bahwa rubrik Fun Science Republika yang dijadikan sebagai objek penelitian termasuk ke dalam wacana yang padu, baik padu di bidang bentuk (kohesi) maupun padu di bidang makna (koherensi). Kepaduan informasi tersebut tentunya diwujudkan oleh konjungsi sebagai salah satu penanda hubungan informasi dan pertalian makna antarkalimat maupun antarparagraf.

Penggunaan konjungsi antarkalimat pada 58 pasang ujaran dengan keseluruhan jumlah 413 kalimat pada kolom utama rubrik Fun Science Republika edisi JanuariApril 2017 dijelaskan pada tabel di bawah ini.

Tabel 2. Frekuensi Pertalian Makna Konjungsi dalam Rubrik Fun Science Republika Januari-April 2017

\begin{tabular}{cc}
\hline $\begin{array}{c}\text { Pertalian Makna } \\
\text { Antarkalimat }\end{array}$ & Frekuensi \\
\hline Penjumlahan & 4 \\
Perturutan & 13 \\
Pertentangan & 12 \\
Lebih & 2 \\
Sebab Akibat & 5 \\
Waktu & 10 \\
Syarat & 2 \\
Cara & 5 \\
Kegunaan & 1 \\
Penjelasan & 4 \\
\hline Total & 58 \\
\hline
\end{tabular}


Penelitian berdasarkan penggunaan konjungsi sebagai pertalian makna antarkalimat diperoleh data sejumlah 58 penanda. Penggunaan tersebut menandai pertalian makna pada sepuluh kategori, yakni pertalian makna penjumlahan diperoleh sebanyak 4 penanda, perturutan 13 penanda, perlawanan 12 penanda, lebih 2 penanda, sebab akibat 5 penanda, waktu 6 penanda, syarat 2 penanda, cara 5 penanda, kegunaan 1 penanda, dan penjelasan 4 penanda.

\section{Grafik 1. Frekuensi Rekapitulasi Pertalian Makna Konjungsi pada Rubrik Fun Science Republika Januari-April 2017}

- Penjumlahan
- Perturutan
- Pertentangan
- Lebih
- Sebab akibat
- Waktu
- Syarat
- Cara
- Kegunaan
- Penjelasan

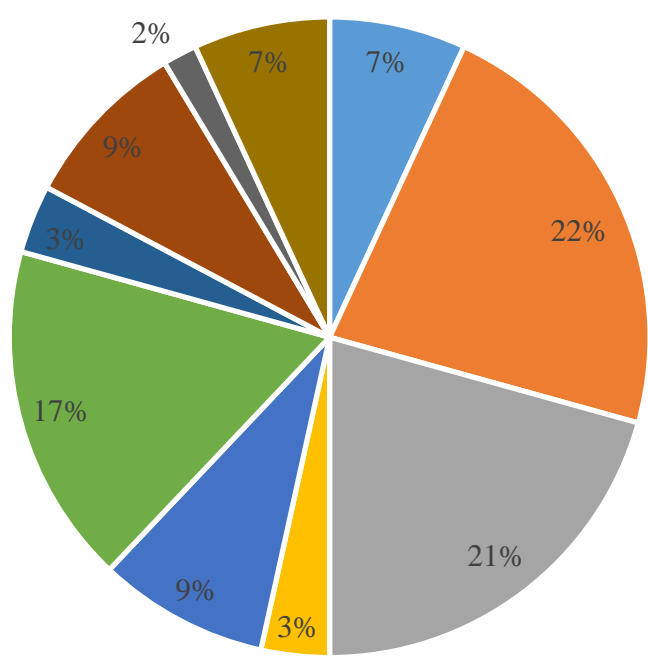

Berdasarkan grafik di atas dapat diketahui bahwa pertalian konjungsi 'perturutan' lebih banyak digunakan sebagai penanda hubungan informasi antarkalimat dengan jumlah $22 \%$. Hal ini terjadi karena rubrik Fun Science Republika lebih banyak menggunaakan informasi perturutan antarkalimat dibanding informasi lainnya. Pengamatan awal menunjukkan bahwa hubungan informasi selain perturutan, seperti penjumlahan, perlawanan, lebih, sebab akibat, waktu, syarat, cara, kegunaan, dan penjelasan lebih banyak menggunakan konjungsi penanda hubungan intrakalimat 
daripada antarkalimat. Di samping itu, informasi perturutan biasanya diwujudkan tidak dalam satu kalimat saja, namun memerlukan beberapa kalimat untuk menyatakan hubungan tersebut. Informasi yang dinyatakan kalimat satu berbeda dengan kalimat setelahnya, tetapi masih memiliki hubungan yang sama dengan topik utama paragraf yang mencakup kalimat tersebut. Dengan demikian, diperlukan konjungsi antarkalimat untuk menghubungkan informasi-informasi tersebut sehingga mendukung topik utama.

Selanjutnya, konjungsi sebagai hubungan dan pertalian makna penjelasan diperoleh $7 \%, 21 \%$ pertentangan, 3\% lebih, 9\% sebab akibat, 17\% waktu, 3\% syarat, $3 \%$ cara, $2 \%$ kegunaan, dan $7 \%$ penjumlahan. Berdasarkan tabel dan grafik di atas dapat disimpulkan bahwa rubrik Fun Science Republika mencapai keseluruhan unit analisis konjungsi sebagai pertalian makna antarkalimat yang dijelaskan menurut Ramlan dalam teorinya, Paragraf: Alur Pikiran dan Kepaduannya dalam Bahasa Indonesia bahwa terdapat sepuluh pertalian antarinformasi yang dinyatakan kalimat-kalimat dalam wacana.

Penggunaan konjungsi sebagai penanda hubungan dan pertalian makna 'penjumlahan' pada rubrik Fun Science Republika ini terjadi persebarannya sejumlah 4 penanda. Hasil persebaran penanda tersebut dijelaskan pada grafik di bawah ini.

\section{Grafik 3. Frekuensi Pertalian Makna 'Penjumlahan' pada Rubrik Fun Science Republika Januari-April 2017}

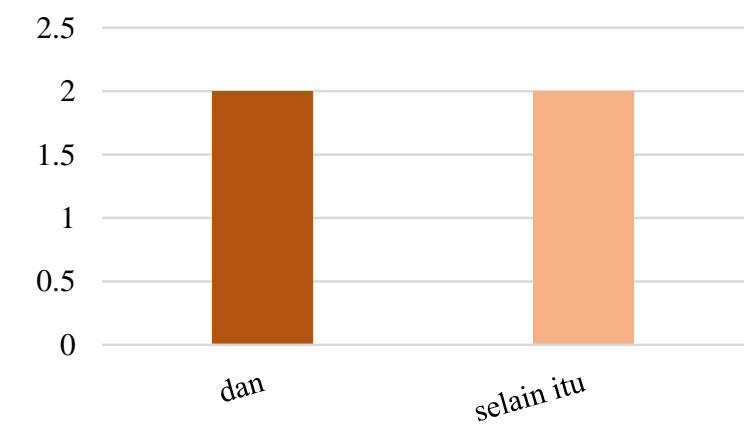


Konjungsi yang digunakan sebagai penanda hubungan dan pertalian 'penjumlahan' hanya terdiri dari dua jenis penanda sesuai dengan penjelasan pada grafik di atas, yaitu penanda dan yang berjumlah 2 dan selain itu yang berjumlah 2.

Penggunaan konjungsi 'penjumlahan' pada rubrik Republika ini hanya menghasilkan satu makna saja dari kedua penanda tersebut, yaitu penanda dan, dan selain itu menyatakan 'tambahan' diantara informasi-informasi yang dihubunginya. Pernyataan yang menyatakan 'tambahan' akan dijelaskan sebagai berikut.

(1) Ilmuwan geologi Barbara Sherwood Lollar dan beberapa anggota dari tim peneliti yang sama kini berhasil menemukan air yang berusia lebih tua, yaitu 2 miliar tahun. Air berusia 2 miliar tahun ini ditemukan di bebatuan prakambrium Canadian Shield. Era prakambrium adalah mulai terciptanya bumi hingga 540 juta tahun yang lalu. Kali ini temuan air ada di kedalaman tiga $\mathrm{km}$. Untuk mengetahui usia air tersebut, peneliti meneliti gas yang larut dalam cairan. (01/P3/K1-K5)

Analisis terhadap gas ini dapat membantu peneliti untuk mengetahui usia atau lama menetapnya air di suatu tempat. Mengapa? Penelitian sebelumnya telah membuktikan bahwa gas mulia yang terperangkap di dalam bebatuan kunoseperti helium, neon, argon, dan xenon yang terjadi dalam rasio berbedaberkaitan dengan era tertentu dalam sejarah bumi. Air berusia tua yang mengalir diantara retakan batu dapat terjebak di dalam retakan tersebut. (01/P4/K1-K4)

Selain itu, peneliti juga menemukan adanya jejak-jejak kimia yang tertinggal dari organisme bersel satu yang pernah hidup di dalam air tersebut. Jejak tersebut menunjukkan organisme tersebut telah muncul dalam skala waktu geologis prakambrium itu. (01/P5/K1-K2)

Kutipan wacana (1) menunjukkan bahwa adanya hubungan informasi antarparagraf. Paragraf (01/P3/K1-K5), (01/P4/K1-K4), dan (01/P5/K1-K2) memiliki hubungan informasi yang menyatakan penjumlahan. Pasang ujaran pertama terdiri dari tiga paragraf. Paragraf-paragraf tersebut dihubungkan dengan menggunakan kon-jungsi selain itu yang berada pada paragraf (01/P5). Konjungsi selain itu yang berada pada paragraf tersebut menghubungkan kalimat pertama pada paragraf (01/P5) "peneliti juga menemukan adanya jejak-jejak kimia yang tertinggal dari organisme bersel satu yang 
pernah hidup di dalam air tersebut" dengan kalimat pertama pada paragraf (01/P3) "ilmuwan geologi Barbara Sherwood Lollar dan beberapa anggota dari tim peneliti yang sama kini berhasil menemukan air yang berusia lebih tua, yaitu 2 miliar tahun".

Selain konjungsi selain itu digunakan sebagai penanda hubungan kalimat pertama pada paragraf (01/P5) dengan kalimat pertama pada paragraf (01/P3), juga menandai pertalian 'penjumlahan'. Informasi yang disampaikan pada kalimat pertama paragraf (01/P5) "peneliti menemukan jejak kimia organisme bersel satu pada air yang ditemukan" merupakan informasi tambahan dari informasi yang dinyatakan pada kalimat pertama paragraf (01/P3) "ilmuwan geologi Barbara Sherwood Lollar dan penelitinya telah berhasil menemukan air yang berusia lebih tua”. Informasi kalimat pertama paragraf (01/P5) adalah bagian dari informasi kalimat pertama paragraf (01/P3), jejak kimia yang ditemukan berada dalam air yang berusia lebih tua itu. Sedangkan, informasi paragraf (01/P4/K1-K4) merupakan informasi tambahan paragraf (01/P3/K1-K5) "cara peneliti mengetahui usia air dengan meneliti gas yang ada dalam air tersebut" merupakan informasi tambahan dari informasi kalimat sebelumnya. Dengan demikian, pasang ujaran pertama merupakan pasang ujaran yang kohesif dan koherens karena paragraf $(01 / \mathrm{P} 5 / \mathrm{K} 1-\mathrm{K} 2)$ dan $(01 / \mathrm{P} 4 / \mathrm{K} 1-\mathrm{K} 4)$ bertalian dengan topik ujaran yang dinyatakan pada paragraf (01/P3/K1-K5) "penemuan air yang berusia lebih tua oleh peneliti" yang dihubungkan dengan penanda selain itu sebagai pertalian 'penjumlahan'.

Pertalian makna 'perturutan' yang digunakan pada rubrik Fun Science Republika ini sebanyak 13 penanda yang tersebar di keempat belas rubriknya. Penggunaan penanda yang berjumlah tiga belas tersebut dijelaskan pada grafik di bawah ini. 


\section{Grafik 4. Frekuensi Pertalian Makna 'Perturutan' pada Rubrik Fun Science Republika Januari-April 2017}

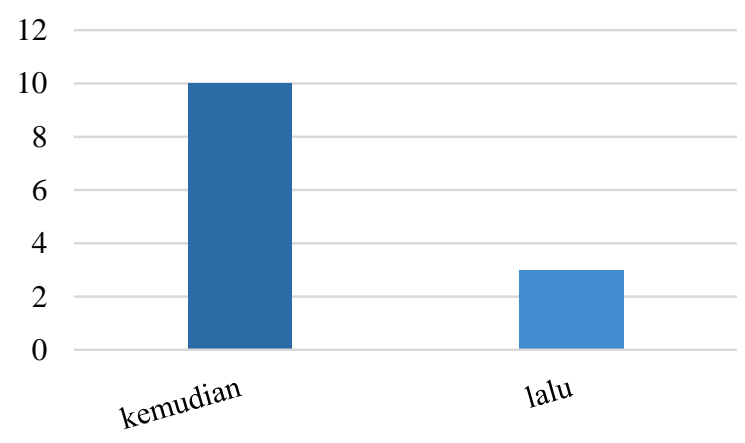

Grafik di atas memberikan gambaran bahwa penanda pertalian 'perturutan' menggunakan 2 jenis penanda, antara lain kemudian dan lalu. Penanda kemudian digunakan sebanyak 10 kali dan penanda lalu digunakan sebanyak 3 kali. Di samping itu, terdapat penanda 'perturutan' yang tidak digunakan di dalam rubrik Fun Science Republika ini, yakni penanda dan. Dengan begitu, dapat disimpulkan bahwa penanda pertalian 'perturutan' yang paling banyak muncul dalam rubrik adalah kemudian yang berjumlah 10 kali penggunaan, sedangkan penanda yang paling sedikit muncul adalah lalu yang berjumlah 3 kali penggunaan.

Penggunaan penanda pertalian 'perturutan' pada rubrik Fun Science ini akan dijelaskan sebagai berikut.

(2) Dalam penelitian terbarunya, Spottiswooe bekerja sama dengan Keith dan Collen Begg. Keduanya merupakan ahli biologi konservasi yang bekerja di Cagar Alam Niassa, Mozambik. Berdasarkan dari penemuan Isack sebelumnya, ketiga ahli biologi ini menemukan, para pemburu madu dari suku Yao dapat menemukan sarang lebah dengan sangat cepat dan hampir tidak pernah meleset. Akurasinya mencapai 75 persen. (02/P7/K1-K4)

Ketiga ahli biologi ini pun kemudian melanjutkan penelitian tentang bagaimana burung penuntun madu dapat merespons panggilan manusia. Orang-orang Yao memanggil burung penuntun madu dengan mengeluarkan suara getaran tertentu. Menurut 20 orang pemburu madu yang diwawancarai, 
suara getaran ini dapat menarik perhatian burung penuntun madu. (02/P8/K1K3)

Penggunaan konjungsi 'perturutan’ pada kutipan ketiga menandai hubungan informasi antarparagraf. Pasang ujaran ketiga terdiri dari dua paragraf yang berbeda. Paragrafparagraf tersebut dihubungkan dengan menggunakan konjungsi kemudian yang menghubungkan kalimat pertama paragraf (02/P8) "ketiga ahli biologi ini pun melanjutkan penelitian tentang bagaimana burung penuntun madu dapat merespons panggilan manusia" dengan kalimat kedua paragraf (02/P7) "ketiga ahli biologi ini menemukan, para pemburu madu dari suku Yao dapat menemukan sarang lebah dengan sangat cepat dan hampir tidak pernah meleset". Selain konjungsi kemudian digunakan sebagai penanda hubungan kalimat pertama paragraf (02/P8) dengan kalimat kedua paragraf (02/P7), juga menandai pertalian 'perturutan'. Informasi yang disampaikan pada kalimat pertama paragraf (02/P8) "ketiga ahli biologi melanjutkan penelitian cara burung penuntun madu merespons panggilan mereka" merupakan tindakan lanjutan dari informasi yang dinyatakan pada kalimat kedua paragraf (02/P7) "ketiga ahli biologi menemukan pemburu madu dari suku Yao dapat menemukan sarang lebah dengan cepat". Perturutan dimulai dari ketiga ahli biologi menemukan pemburu madu dapat menemukan sarang madu dengan sangat cepat kemudian mereka meneliti cara burung merespon panggilan pemburu dari suku Yao. Sedangkan, informasi kalimat kedua sampai ketiga pada paragraf $(02 / \mathrm{P} 8)$ "cara orang Yao memanggil burung penuntun madu sehingga burung dapat merespon panggilan mereka" merupakan informasi tambahan dari topik paragraf tersebut. Selanjutnya, kalimat pertama paragraf (02/P7) merupakan topik paragraf tersebut "kerja sama antara Spottiswooe dengan Keith dan Collen Begg”. Dengan demikian, pasang kalimat ujaran keenam merupakan pasang 
kalimat yang kohesif dan koherens karena paragraf (02/P8/K1-K3) bertalian dengan topik ujaran yang dinyatakan pada kalimat pertama paragraf (02/P7) "kerja sama antara Spottiswooe dengan Keith dan Collen Begg terhadap burung penuntun madu dan suku Yao” yang dihubungkan dengan penanda kemudian sebagai pertalian 'perturutan'.

Konjungsi sebagai penanda hubungan dan pertalian makna 'pertentangan' pada rubrik Fun Science Republika diperoleh jumlah penanda yang digunakan sebanyak 12 penggunaan. Penggunaan penanda tersebut dijelaskan sebagai berikut.

\section{Grafik 5. Frekuensi Pertalian Makna 'Pertentangan' pada Rubrik Fun Science Republika Januari-April 2017}

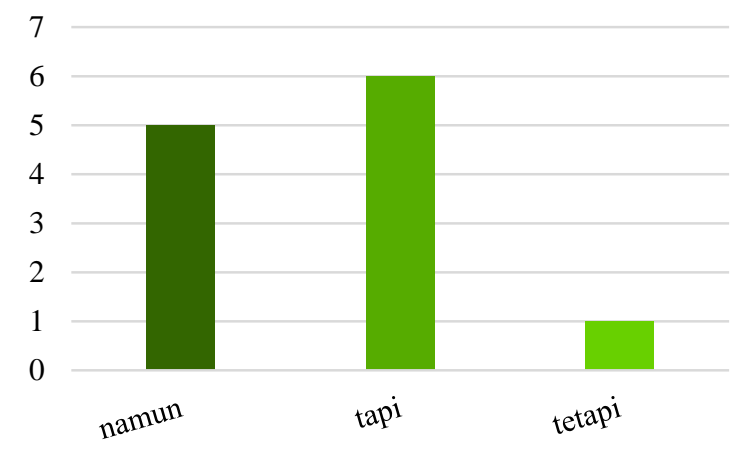

Grafik diatas menunjukkan bahwa konjungsi sebagai penanda hubungan dan pertalian 'pertentangan' menggunakan 3 jenis penanda yang berbeda dalam menghubungkan informasi antarkalimat dalam wacana. Ketiga jenis itu adalah penanda namun dengan jumlah 5 kali penggunaan, penanda tapi dengan jumlah 6 kali penggunaan, dan penanda tetapi dengan jumlah 1 kali penggunaan. Penggunaan penanda 'pertentangan' dijelaskan pada contoh di bawah ini.

(3) Hingga saat ini, belum ada penelitian yang membuktikan sejak usia kapan burung penuntun madu memiliki kemampuan membedakan panggilan ini. Burung penuntun madu muda hampir tidak memiliki kesempatan mempelajari cara ini dari induk biologis mereka. Namun, Thomp son menduga burung penuntun madu secara historis telah memiliki gaya hidup menuntun manusia ke sarang madu. (02/P11/K1-K3) 
Kutipan ketujuh menggambarkan penggunaan konjungsi namun sebagai penanda hubungan informasi antarkalimat. Pasang kalimat ujaran ketujuh terdiri dari tiga kalimat. Kalimat-kalimat tersebut dihubungkan dengan menggunakan konjungsi namun yang menghubungkan kalimat $(02 / \mathrm{P} 11 / \mathrm{K} 3)$ "Thomp son menduga burung penuntun madu secara historis telah memiliki gaya hidup menuntun manusia ke sarang madu" dengan kalimat $(02 / \mathrm{P} 11 / \mathrm{K} 2)$ "burung penuntun madu muda hampir tidak memiliki kesempatan mempelajari cara ini dari induk biologis mereka".

Selain konjungsi namun digunakan sebagai penanda hubungan kalimat (02/P11/K3) dengan kalimat (02/P11/K2), juga menandai pertalian 'pertentangan'. Informasi yang disampaikan pada kalimat (02/P11/K3) "Thomp son menduga burung penuntun madu muda sudah memiliki gaya hidup menuntun manusia ke sarang madu sejak dahulu" berlawanan dari informasi yang dinyatakan pada kalimat (02/P11/K2) "burung penuntun madu tidak memiliki kesempatan mempelajari perbedaan panggilan yang dibuat manusia untuk membantu mereka ke sarang lebah dari induknya". Di samping itu, kalimat (02/P11/K1) merupakan topik paragraf terhadap informasi kalimat setelahnya "tidak ada penelitian yang dapat membuktikan waktu pertama kali burung penuntun madu dapat membedakan panggilan yang digunakan manusia untuk meminta bantuan menuntunnya ke sarang lebah". Dengan demikian, pasang kalimat ujaran ketujuh merupakan pasang kalimat yang kohesif dan koherens karena kalimat $(02 / \mathrm{P} 11 / \mathrm{K} 2)$ dan $(02 / \mathrm{P} 11 / \mathrm{K} 3)$ bertalian dengan topik ujaran yang dinyatakan pada kalimat (02/P11/K1) "tidak ada penelitian yang dapat membuktikan waktu pertama kali burung penuntun madu dapat membedakan panggilan yang digunakan manusia untuk meminta bantuan menuntunnya ke sarang lebah" yang dihubungkan dengan penanda namun sebagai pertalian 'pertentangan'. 
Konjungsi sebagai penanda hubungan dan pertalian makna 'lebih' pada rubrik Fun Science Republika diperoleh jumlah penanda yang digunakan sebanyak 2 penggunaan. Hasil penelitian terhadap penggunaan penanda tersebut dijelaskan pada grafik sebagai berikut.

\section{Grafik 6. Frekuensi Pertalian Makna 'Lebih' pada Rubrik Fun Science Republika Januari-April 2017}

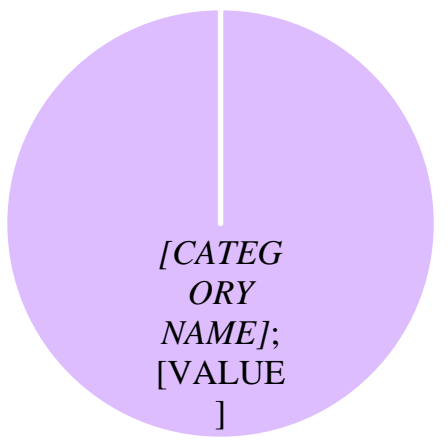

Grafik tersebut menunjukkan bahwa penggunaan konjungsi 'lebih' hanya menggunakan satu jenis penanda, yaitu bahkan dengan jumlahnya sebanyak 2 kali pemunculan dari keempat belas rubrik yang dianalisis.

Penggunaan penanda bahkan yang berjumlah dua sebagai sebagai penanda hubungan dan pertalian makna 'lebih' digambarkan pada kutipan di bawah ini.

(4) Menurut para ilmuwan, yang dipublikasikan pertengahan Februari lalu, kedua fosil tikus itu membantu memberikan gambaran yang lebih lengkap mengenai hewan pengerat raksasa yang pernah hidup jutaan tahun lalu. Sejumlah spesies hewan pengerat raksasa dulunya banyak terdapat di Amerika Selatan. Hal itu berlangsung selama periode Miosen atau sekitar 23 juta tahun hingga 5,3 juta tahun yang lalu. Bahkan, menurut sebuah penelitian yang diterbitkan Journal of Anatomy pada Februari 2016, tikus raksasa yang pernah digambarkan sebelumnya Josephoartigasia monesi, diperkirakan memiliki ukuran sebesar kerbau dengan kekuatan gigitan setajam harimau. Namun, sebagian besar garis keturunan tikus raksasa ini telah mengalami kepunahan. Beberapa yang masih tersisa, yaitu capybara yang beratnya bisa mencapai 79 kilogram. Tikus capybara yang dikenal juga dengan sebutan babi air ini ditemukan di Amerika Tengah dan Amerika Selatan. Baru-baru ini capybara juga ditemukan di California. (14/P2/K1-K8) 
Kutipan kesebelas menggambarkan penggunaan konjungsi bahkan sebagai penanda hubungan informasi antarkalimat. Pasang kalimat ujaran kesebelas terdiri dari delapan kalimat. Kalimat-kalimat tersebut dihubungkan dengan menggunakan konjungsi bahkan yang menghubungkan kalimat $(14 / \mathrm{P} 2 / \mathrm{K} 4)$ "tikus raksasa yang pernah digambarkan sebelumnya Josephoartigasia monesi, diperkirakan memiliki ukuran sebesar kerbau dengan kekuatan gigitan setajam harimau, menurut sebuah penelitian yang diterbitkan Journal of Anatomy pada Februari 2016" dengan kalimat (14/P2/K2-K3) "Sejumlah spesies hewan pengerat raksasa dulunya banyak terdapat di Amerika Selatan. Hal itu berlangsung selama periode Miosen atau sekitar 23 juta tahun hingga 5,3 juta tahun yang lalu".

Selain konjungsi bahkan digunakan sebagai penanda hubungan kalimat (14/P2/K4) dengan kalimat (14/P2/K2-K3), juga menandai pertalian 'lebih'. Informasi yang disampaikan pada kalimat (14/P2/K4) "tikus raksasa, Josephoartigasia monesi diperkirakan memiliki ukuran sebesar kerbau dengan kekuatan gigitan setajam harimau" memberikan pernyataan yang melebihi dari informasi kalimat (14/P2/K2-K3) "dahulu, sejumlah spesies hewan pengerat raksasa banyak terdapat di Amerika selatan selama periode Miosen atau sekitar 23-5,3 juta tahun yang lalu”. Jadi, pertalian 'lebih' yang disampaikan pada kalimat $(14 / \mathrm{P} 2 / \mathrm{K} 4)$ berkenaan bukan hanya sekadar tikus raksasa yang hidup Amerika selatan selama periode Miosen, tetapi juga memiliki ukuran sebesar kerbau dengan kekuatan gigitan setajam harimau. Di samping itu, kalimat (14/P2/K1) menyatakan topik paragraf terhadap kalimat setelahnya "fosil tikus raksasa memberikan gambaran kehidupan hewan pengerat raksasa yang hidup jutaan tahun lalu". Selanjutnya, kalimat (14/P2/K5-K8) menyatakan informasi mengenai keadaan sekarang dari keturunan hewan pengerat raksasa bahwa hewan tersebut sudah 
mengalami kepunahan dan hewan yang tersisa adalah tikus capybara dengan berat mencapai 79 kilogram yang ditemukan di Amerika Selatan serta California. Dengan demikian, pasang kalimat ujaran kesebelas merupakan pasang kalimat yang kohesif dan koherens karena kalimat (14/P2/K2-K8) bertalian dengan topik ujaran yang dinyatakan pada kalimat (14/P2/K1) "penemuan fosil tikus raksasa memberikan gambaran kehidupan hewan pengerat raksasa yang hidup jutaan tahun lalu" yang dihubungkan dengan penanda bahkan sebagai pertalian 'lebih'.

Penggunaan konjungsi sebagai penanda hubungan informasi dan pertalian makna 'sebab akibat' yang digunakan pada rubrik Fun Science Republika ini berjumlah 5 penanda dengan persebarannya sebagai berikut.

\section{Grafik 7. Frekuensi Pertalian Makna 'Sebab Akibat' pada Rubrik Fun Science Republika Januari-April 2017}

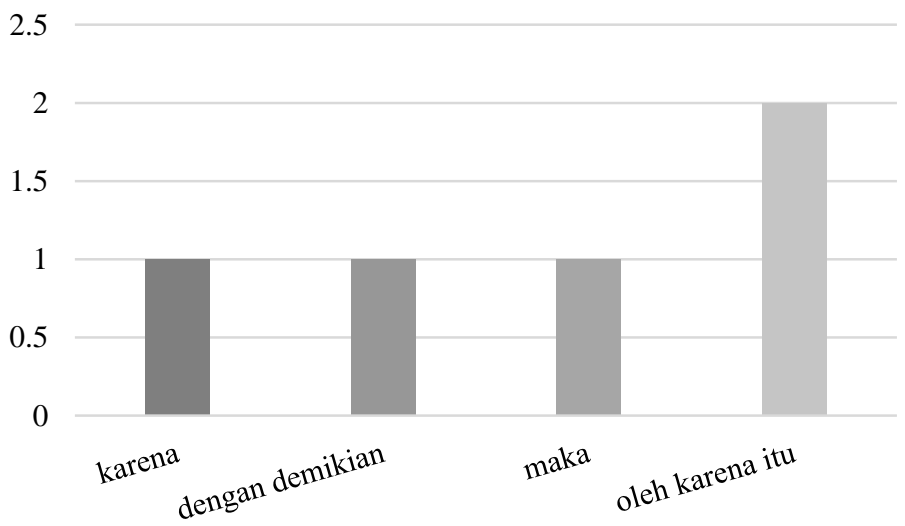

Persebaran konjungsi sebagai penanda hubungan dan pertalian makna 'sebab akibat' pada rubrik tersebut menggunakan 4 jenis penanda yang berbeda sesuai penggambaran grafik. Keempat jenis tersebut diantaranya penanda karena sebanyak 1 kali penggunaan, penanda dengan demikian sebanyak 1 kali penggunaan, penanda maka sebanyak 1 kali penggunaan, dan penanda oleh karena itu sebanyak 2 kali penggunaan. 
Penggunaan penanda pertalian 'sebab akibat' dalam rubrik Fun Science dijelaskan pada kutipan di bawah ini.

(5) Adalah Nicolas Houlié, seorang ahli geofisika di ETH Zurich, yang pertama kali tahu tentang potensi sistem peringatan dini ini pada 2001. Yakni, ketika melihat sebuah citra satelit, ia melihat garis hijau pepohonan sepanjang tiga kilometer di sisi utara-timur dari Gunung Etna, Sisilia, Italia. Jalur ini mencerminkan vegetasi mengalami perkembangan di daerah itu. Tapi yang membuat penemuan benar-benar menakjubkan adalah gunung berapi meletus dan lavanya mengalir di sepanjang garis yang sama pada satu tahun kemudian. (13/P3/K1-K4)

Aneh, ya? Tidak kalau menurut para ilmuwan. Maka para ahli lintas disiplin ilmu pun meneliti. Yakni, dendrokronologi, ilmu yang mempelajari lingkaran tahunan pohon untuk menetapkan waktu dan kronologi peristiwa di masa lalu dan ahli geografi alias pakar ilmu bumi. (13/P4/K1-K4)

Kutipan kedua belas merupakan penggambaran penggunaan konjungsi maka sebagai penanda hubungan informasi antarparagraf. Pasang ujaran kedua belas terdiri dari dua paragraf. Paragraf-paragraf tersebut dihubungkan dengan menggunakan konjungsi maka yang menghubungkan paragraf (13/P4/K1-K4) "para ahli lintas disiplin ilmu pun meneliti yakni, dendrokronologi, ilmu yang mempelajari lingkaran tahunan pohon untuk menetapkan waktu dan kronologi peristiwa di masa lalu dan ahli geografi alias pakar ilmu bumi" dengan paragraf (13/P3/K1-K4) "Nicolas Houlié, seorang ahli geofisika di ETH Zurich, yang pertama kali tahu tentang potensi sistem peringatan dini ini pada 2001 ketika melihat sebuah citra satelit, ia melihat garis hijau pepohonan sepanjang tiga kilometer di sisi utara-timur dari Gunung Etna, Sisilia, Italia. Jalur ini mencerminkan vegetasi mengalami perkembangan di daerah itu. Tapi yang membuat penemuan benarbenar menakjubkan adalah gunung berapi meletus dan lavanya mengalir di sepanjang garis yang sama pada satu tahun kemudian.”.

Selain konjungsi maka digunakan sebagai penanda hubungan paragraf (13/P4/K1-K4) dengan paragraf (13/P3/K1-K4), juga menandai pertalian 'sebab 
akibat'. Informasi yang disampaikan pada paragraf (13/P4/K1-K4) "para ahli lintas disiplin ilmu meneliti, yakni dendrokronologi dan ahli geografi" menyatakan akibat dari informasi paragraf (13/P3/K1 -K4) "penemuan Nicolas Houlié, seorang ahli geofisika di ETH Zurich terhadap penglihatannya pada garis hijau pepohonan sepanjang tiga kilometer di sisi utara-timur dari Gunung Etna, Sisilia, Italia mengakibatkan gunung berapi meletus dan lavanya mengalir di sepanjang garis yang sama pada satu tahun kemudian". Jadi, kedua informasi tersebut menyatakan bahwa para ahli lintas disiplin ilmu melakukan penelitian karena adanya kaitan erat antara garis hijau pepohonan sepanjang tiga kilometer di sisi utara-timur dari Gunung Etna, Sisilia, Italia dengan peristiwa gunung meletus yang terjadi satu tahun kemudian. Dengan demikian, pasang ujaran kedua belas merupakan pasang kalimat yang kohesif dan koherens karena kalimat (13/P3/K2-K4) dan paragraf (13/P4/K1-K4) bertalian dengan topik ujaran yang dinyatakan pada kalimat pertama paragraf (13/P3) "penemuan potensi peringatan dini gunung meletus oleh Nicolas Houlié” yang dihubungkan dengan penanda maka sebagai pertalian 'sebab akibat'.

Penelitian ini tentunya memiliki implikasi sebagai tindak lanjut dari hasil yang ditemukan. Tindak lanjut tersebut berupa perancangan rencana pelaksanaan pembelajaran konjungsi pada teks eksposisi jenjang SMP kelas VIII Kurikulum 2016 Revisi 2013. Perancangan rencana pelaksanaan pembelajaran mengacu kepada Kompetensi Dasar 3.6 dan 4.6. KD 3.6 yaitu mengidentifikasi struktur, unsur kebahasaan, dan aspek lisan dalam teks eksposisi artikel ilmiah populer (lingkungan hidup, kondisi sosial, dan/atau keragaman budaya, dll) yang diperdengarkan atau dibaca. KD 4.6 yakni menyajikan gagasan dan pendapat ke dalam bentuk teks eksposisi artikel ilmiah populer (lingkungan hidup, kondisi sosial, dan/atau keragaman budaya, 
dll) secara lisan dan tertulis dengan memperhatikan struktur, unsur kebahasaan, dan aspek lisan. Kedua kompetensi dasar ini sesuai dijadikan pijakan pedoman perancangan rencana pelaksanaan pembelajaran karena konjungsi merupakan salah satu unsur kebahasaan yang harus ada dalam teks eksposisi dan rubrik Fun Science Republika dapat dijadikan sebagai media pembelajaran teks eksposisi.

Dalam pembelajaran konjungsi, guru perlu memerhatikan beberapa hal cara pengajaran materi tersebut. Guru perlu memerhatikan penggunaan konjungsi dengan menggunakan konteks kalimat agar siswa mengetahui secara langsung penggunaan konjungsi yang dimaksud dalam kalimat serta mengetahui perbedaan penggunaan konjungsi yang satu dengan lainnya. Akibatnya, siswa akan mudah menerapkan penggunaan konjungsi tersebut dalam kegiatan memproduksi tulisan dan pengetahuan siswa menjadi tidak terbatas terhadap konjungsi bahasa Indonesia.Pembelajaran konjungsi sebagai pertalian makna antarkalimat tidak dapat serta merta diajarkan secara langsung kepada siswa karena konjungsi yang diajarkan berupa konjungsi antarkalimat. Dengan demikian, hal yang perlu dilakukan sebelum pembelajaran, antara lain.

1. Guru menentukan salah satu wacana yang akan diajarkan kepada siswa sebagai media pembelajaran unsur kebahasaan konjungsi. Hal ini perlu dilakukan agar guru mengetahui konjungsi yang digunakan dalam wacana tersebut.

2. Guru memerhatikan penggunaan konjungsi apa saja yang digunakan dalam pilihan wacana. Konjungsi yang digunakan tentunya tidak hanya mencakup konjungsi antarkalimat saja, namun juga terdapat konjungsi intrakalimat. Hal tersebut adalah hal yang terpenting yang harus dilakukan guru karena guru tidak dapat langsung mengajarkan konjungsi antarkalimat. 
3. Guru mengklasifikasikan penanda-penanda yang termasuk dalam konjungsi intrakalimat dan antarkalimat.

4. Guru menentukan unsur-unsur penghubung dari masing-masing konjungsi intrakalimat dan antarkalimat.

5. Guru menentukan hubungan-hubungan yang dihasilkan dari masing-masing konjungsi berdasarkan konjungsi intrakalimat dan antarkalimat pada wacana yang telah dipilihnya.

Setelah guru melakukan beberapa langkah yang harus dilakukan sebelum pembelajaran konjungsi antarkalimat, guru melakukan pembelajaran dengan langkah sebagai berikut.

1. Siswa diminta untuk menemukan konjungsi yang berada pada wacana yang telah diberikan oleh guru. Hal ini dilakukan untuk menstimulus pengetahuan siswa terhadap konjungsi dan guru bisa mengetahui tingkat pengetahuan mereka.

2. Siswa dan guru mendaftar konjungsi yang digunakan dalam wacana pada media papan tulis. Semua konjungsi yang ada di wacana didaftar terlebih dahulu. Jangan menggunakan langkah pembelajaran dengan mengklasifikasi-kan konjungsikonjungsi tersebut secara langsung.

3. Setelah semua konjungsi didaftar, masing-masing konjungsi tersebut ditentukan unsur penghubungnya. Tahap ini adalah langkah pembelajaran yang penting dimana siswa harus bisa menentukan unsur wacana yang dihubungkan oleh konjungsi.

4. Jika semua konjungsi sudah ditentukan unsur penghubungnya, siswa akan dengan sendirinya dapat menentukan konjungsi intrakalimat dan antarkalimat. 
5. Siswa diminta untuk menyimpulkan secara mandiri makna yang dihasilkan dari unsur-unsur yang dihubungkan oleh konjungsi dengan perkiraan mereka.

6. Guru memeriksa hasil perkiraan siswa terhadap makna konjungsi tersebut dengan menjelaskan hubungan makna yang dihasilkan dari unsur-unsur penghubung konjungsi. Tahap ini dijelaskan pada gambar di bawah ini.

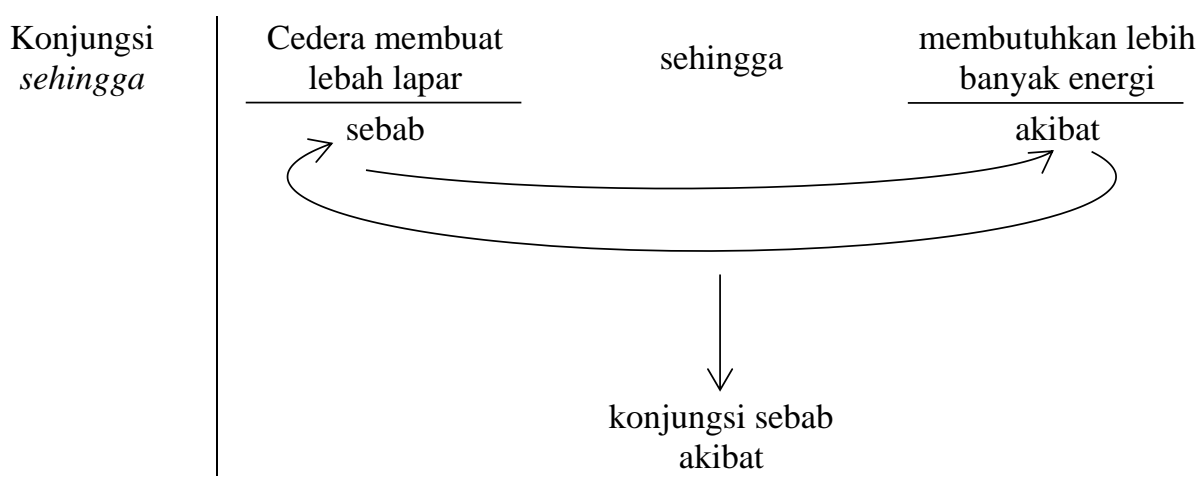

Pada tahap ini, guru menjelaskan hubungan makna berdasarkan urutan konjungsi yang digunakan pada masing kalimat satu. Konjungsi yang berada di kalimat satu, dilanjutkan ke kalimat dua, dan seterusnya. Namun, perlu diperhatikan jika terdapat penggunaan konjungsi antarkalimat, maka penjelasannya dilompati. Hal ini dilakukan agar siswa lebih mengetahui penggunaan konjungsi intrakalimat terlebih dahulu daripada konjungsi antarkalimat.

7. Apabila semua konjungsi intrakalimat sudah dianalisis hubungan makna yang dihasilkan, maka guru melanjutkan pembelajaran hubungan makna pada konjungsi antarkalimat pada hari yang berbeda.

8. Langkah pembelajaran hubungan makna konjungsi antarkalimat sama halnya dengan langkah keenam dan seterusnya. 


\section{KESIMPULAN}

Konjungsi sebagai pertalian makna antarkalimat pada rubrik Fun Science Republika edisi Januari-April 2017 dapat disimpulkan bahwa keempat belas rubrik tersebut dapat mempertahankan keutuhan wacananya, yakni kohesi dan koherensi. Hal ini dapat dibuktikan bahwa keseluruhan pasang ujaran yang dianalisis dengan jumlah 58 pasang kohesif dan koherens. Tentunya kohesif dan koherensnya rubrik tersebut ditentukan oleh salah satu penanda hubungan, yaitu konjungsi yang digunakan sebagai penanda hubungan dan pertalian makna informasi yang dinyatakan kalimat yang satu dengan kalimat yang lain. Informasi-informasi tersebut bertalian satu sama lain dan mendukung adanya keserasian terhadap topik pada masing-masing ujaran.

Penelitian berdasarkan penggunaan konjungsi sebagai pertalian makna antarkalimat diperoleh data sejumlah 58 penanda dari 58 pasang ujaran. Penggunaan tersebut menandai pertalian makna pada sepuluh kategori, yakni pertalian makna penjumlahan diperoleh sebanyak 4 penanda, perturutan 13 penanda, perlawanan 12 penanda, lebih 2 penanda, sebab akibat 5 penanda, waktu 6 penanda, syarat 2 penanda, cara 5 penanda, kegunaan 1 penanda, dan penjelasan 4 penanda.

\section{UCAPAN TERIMA KASIH}

Dengan ketulusan hati, penulis mengucapkan terima kasih kepada semua pihak yang telah membantu dalam menyelesaikan penelitian ini.

\section{DAFTAR PUSTAKA}

Chaer, Abdul. (2010). Bahasa jurnalistik. Jakarta: Rineka Cipta. 
Kurniadi, F. (2017). Penulisan karya tulis ilmiah mahasiswa dengan media aplikasi pengolah kata. Aksis: Jurnal Pendidikan Bahasa dan Sastra Indonesia, 1(2). 267-277. doi: doi.org/10.21009/AKSIS.010208

Ramlan, M. (1993). Paragraf: Alur pikiran dan kepaduannya dalam bahasa Indonesia. Yogyakarta: Andi Offset.

Tarigan, H. G. (1987). Pengajaran wacana. Bandung: Angkasa.

Utami, S. R. (2017). Pembelajaran Aspek Tata Bahasa dalam Buku Pelajaran Bahasa Indonesia. Aksis: Jurnal Pendidikan Bahasa dan Sastra Indonesia, 1(2). 189203. doi: doi.org/10.21009/AKSIS.010203 